UNTAG Law Review (ULREV)

Volume 1, Issue 2, Nov 2017, PP 19-29

ISSN 2549-4910 (online) \& ISSN 2579-5279 (print)

http://jurnal.untagsmg.ac.id/indeks.php/ulrev/indeks

www.fakhukum.untagsmg.ac.id

\title{
A THREE-PILLAR SYNERGISM REINFORCEMENT \\ MODEL IN JUDICIAL FUNCTION POLICY AT VILLAGE LEVEL
}

\author{
Mukhlis, Safi, Rina Yulianti \\ Fakultas Hukum Universitas Trunojoyo Madura, \\ contact at email : mukhlishve@gmail.com
}

\begin{abstract}
The poor people's difficult access to formal judicature system, in fact, has been a national problem, as indicated with previous studies. Although the largescale change of justice access has been made by government through a variety of policies such as justice program for everyone including poor people and marginalized group in Presidential Instruction Number 3 of 2010, mobile justice system, in fact, has not been able to give the way out. This study was a nondoctrinal/socio legal research law taken place in Madura area. The objective of research was to formulate A Three-Pillar Synergism Reinforcement Model in Judicial Function Policy at Village Level as one of juridical instrument or legal basic argument for formulating and developing policy at village government. The result of research showed that in Madura area, considering inventorying and identification, the legal problem encountered by poor people in village included trading, inheritance, land, debt-loan disputes, drugs, domestic violence, murder, chicken fighting and different faiths. Law Number 6 of 2014 about Village Government, Article 28 obliges the Village Head to resolves a variety disputes occurring in village, it is also supported by Republic of Indonesia Police Head Regulation (Peraturan Kapolri) Number 7 of 2008 about Basic Guideline of People Policing Strategy and Implementation in Organizing Polri's Duty, and furthermore followed up with Telegram Letter of East Java Local Police Head Number: ST/38/I/2014/ DITBINMAS on January 2014 about the optimization of Pre-emptive activity by empowering the three pillars existing at village (bhabinkamtibmas, babinsa, and village head/lurah as well as society leader). Polri Institution's initiative to empower the community in Kamtibmas (society orderliness and security) field should be appreciated, as it will encourage the creation of justice access at village level cheaply, quickly, and simply. This three pillar legitimacy can be formulated in government policy model at village level with the reinforcement through Village Regulation.
\end{abstract}

Keywords : Three pillar, judicial function, justice access, village government.

\section{INTRODUCTION}

This further study on poor people's access to justice is conducted due to previous legal studies still focusing on formal law system: police, attorney, and court with recommendation as the output, with the similar focus of study. Meanwhile, legal and justice issues are not only the problem of legal institutions or state organs but also pertaining to the attempt of enforce justice 
comprehensively for Indonesian people corresponding to commitment of Indonesia state government organization based on Independency Proclamation on August 17, 1945 to liberate all Indonesian people from the colonialism's handcuff politically, economically, and socioculturally, so that independent Indonesian human free of any colonialism forms can be realized, and all rights of citizens, particularly the right to reasonable livelihood can be fulfilled. Thus, the law reform strategy and the improvement of society's access to justice should involve all areas.

Reasonable livelihood for Indonesian people is not only viewed from economic glasses only, including the feasibility to get equal treatment before the law, particularly the poor and marginalized people. However at reality level, many Indonesian people still live in misery and far away from the feeling of justice. The problems include firstly: Formal judicature system specified in the constitution and judicial power law is still available at Regency Level; it becomes distinctive constraint to the people, particularly poor people in the village to interact through this mechanism; secondly: when the poor people are dealing with law, they cannot access formal judicial system easily due to expensive cost and long time, while it should be cheap and quick as specified in the Judicial Power Law; thirdly: high apathy of society, particularly poor people, to formal system generates the public's options in accessing justice with informal mechanism that is basically illegitimated and often discriminative and not in line with constitutional guarantee to Human Rights; unfortunately although it becomes main references at Village level, this mechanism has not been institutionalized and has not had law certainty. For that reason, the initiative to expand the poor people's access to justice is required viewed from the reform of judicial institutional structure and the change of grass-root and affordable regulation.

\section{PROBLEM STATEMENT}

Polri Institution's Initiative to empower people in Kamtibmas (society orderliness and security) field should be appreciated, as it will encourage the creation of justice access at village level cheaply, quickly, and simply. Unfortunately, these three pillars have not been institutionalized in a medium integrated into village government system so that it is vulnerable and its performance is ineffective as it has no law binding clearly its institutional mechanism. This research will study the following problems:

1. Inventorying and identification lists of legal issues in village

2. Three-pillar reinforcing policy model at village level.

\section{METHOD}

The type of research used to achieve the objective of research was empirical or non-doctrinal law research, or called socio legal research, in this case, emphasizing on the law functioning in the society.

\section{DISCUSSION}

\section{Inventorying and Identification of Legal issues encountered by poor people in village}

Most villages in Indonesia have poor area pouches often encountering legal problem. The legal problem is not only related to criminal law (criminality) problem, but also other legal problem in daily life related to civil law (e.g. trading, leasing, debt-loan, etc) and government law (certification, deeds, land use, condemnation, etc). Those problems are often undetected

1 Bambang Sunggono, 2010, Metodologi Penelitian Hukum, Raja Grafindo Persada, Jakarta, p. 43 
and do not surface because the rural poor people's incapability of revealing it and of obtaining justice in legal field against those problems. These law problems often 'disturb' society in obtaining its welfare. The Inventorying and Identification List (Daftar Inventarisasi dan Identifikasi, thereafter called DII) of rural poor people's legal problem is important here, to lead the government to pay attention and to give solution to the establishment of village judicial function institution affordable to poor people.

The public's perception on any legal problem occurring in the village is only stuck on the problems related directly to criminality affairs such as murder, rape, robbery, and other crime commonly occurring and becoming media's news coverage. Meanwhile, when observed more seriously, there are many types of problem pertaining to various legal fields in daily life, such as competition for inheritance, debt-loan, land deed administration, trading, and other legal problems.

Many legal problems the people face sometimes do not end up in formal path of resolution as specified by legislation. It is because of inadequate information related to the legal resolution procedure. The alternative way taken is usually to employ village apparatus, society leader, kyai (Islam teacher), and even no attempt is taken because the people is legal illiterate. From some sources collected, some legal problems the villagers encounter that can be inventoried are:

\section{a. Trading}

Generally, trading is defined as an agreement in which one party binds itself to give or to transfer a certain material object, while another pays the object with promised price; it is this the trading formulation defined in Article 1375 of Civil Code (KUH Perdata). Thus, the basic element of trading case is the availability of good (object) and price.

Trading is an activity conducted by individuals in their life sustainability. Without trading activity, human life will not be sustainable in the context of society, nation and state. In other words, trading is the heart of human beings' life, because through trading, human beings can meet all of their life needs.

In reality, in some villages, many trading transactions occurring are harmful to one party, particularly poor people in many inland villages. In its trading activity, people often suffer from many loses related to the product they receive from the sellers that is in fact inconsistent with what has been agreed. In this case, people find difficult in complaining for the loss. When the complaint is delivered directly, the sellers will of course ignore it. Meanwhile, when it is delivered through legal process, it will be more complicated and take longer time.

The society in trading activity is a legal problem coloring the villager life. However, this problem is difficult to solve. Therefore, there should be a further attempt of providing legal construction facilitating the people in solving all of their problems.

\section{b. Inheritance Law}

Regarding inheritance, KUH Perdata does not give a definition of inheritance. However Article 171 of Presidential Instruction No.1 of 1991 mentions that inheritance is the law governing the transfer of right to the ownership of heir's property and then determining who deserves to be beneficiaries and the proportion of property received by each of beneficiaries.

In some rural areas in Madura, inheritance problem is the one often occurring in its society's daily life. Even some families should become enemies due to the competition for inheritance. Even several source mentions that, on average, inheritance problem occupies $30 \%$ of problem 
making the family disunited.

Regarding its resolution, people usually take kinship and discussion approach expecting that there will be proficient understanding related the disputed inheritance problem. However, this method does not solve the problem suddenly, and even some problems end up in violence such as quarrel and duel.

Therefore, a new law construction is needed in the village that provides and promises facilitation in resolving inheritance law between those in dispute.

\section{c. Debt-loan}

In addition to trading and inheritance, another legal problem becoming the issue in villager law is debt-loan problem. The definition of debt-loan itself is not mentioned in KUH Perdata, but Article 1754 of KUH Perdata implies that in entering into loan agreement, the borrower is obliged to repay in the same form and quality. Thus, debt-loan, in this definition, belongs to general category, lending-borrowing.

In practice, many legal problems occurring in the society are related to this debt-loan, and the occurrence is found easily in rural area. Generally, legal problem of debt-loan occurs because one party does not perform its obligation to repay its loan to another. The legal problem related to this debt-loan occurs because the lender imposes fines out of the agreement.

Generally, the debt-loan problem in rural areas is solved between the parties likely generating the loss in each of parties. The expectation for the resolution regulation pattern through village judicial institution is an idea, the implementation of which is waited for amid the society life.

\section{d. Land problem}

Land problem is a legal problem indeed often occurring in rural areas. Even in some northern areas of Madura, this problem often ends up in anarchism or duel. The land problem is not trivial one; it is due to villagers' reliance on farming for their life sustainability. The land problems occur in several forms with different objects of legal problem.

In addition, land problem is also the problem making villagers confused in solving it. This confusion is due to the complicated process and the length of time taken to deal with land affairs. Thus, a new law construction is needed to solve the legal problems regarding land affairs easily and quickly.

\section{e Domestic Violence}

Domestic violence often becomes a problem occurring in rural society. This problem is still found in several places in Madura. This problem occurs due to poor understanding on the importance of building a good and happy family. It is because of very limited/poor economy, low education, and limited intercourse scope factors. These conditions then trigger domestic violence in rural society.

\section{f. Cockfighting gambling}

Cockfighting activity is conducted by many people in many areas in Madura. The main problem in this cockfighting activity is accompanied with gambling. Thus, cockfighting activity is identical with cockfighting gambling. This activity is conducted widely particularly in inland area unaffordable to police apparatuses. In national law, particularly Article 303 of Penal Code, gambling is defined as any activities in which the probability of getting profit is dependent on fortune only. It is a bet on any decision of competition or game resulting in profit from the result of competition. 
The national law has outlined that the crime related to this cockfighting can be punished with 10-year imprisonment or fine of IDR.25 millions; however, despite the punishment threat, some people still do this activity in rural areas.

Related to this cockfighting gambling, people in Tlambah Village of Sampang Regency have efficacious ways of ceasing this activity. One of them is to build mutual commitment between society leaders, Polres Sampang (Resort Police of Sampang), and local people, conducted in NU MWC Secretariat of KarangPenang, Sampang, on January 21, 2016. This activity was conducted on the initiative of NU MWC Karangpenang Sampang. This activity successfully swept the cockfighting gambling practice upsetting the people of Karangpenang so far.

\section{g. Drugs}

Drug addicted is an incurable disease. Although government has imposed maximum sanction, death sentence, against every perpetrator of drug crime, and even government decides status "Indonesia darurat narkoba (Indonesia is in drug emergency)". The increasing number of drug abusers and circulator spreads to several local areas, one of which is Madura; even one of areas in Madura is known as kampung narkoba (drug village), that is, parseh village, Socah Bangkalan Sub District. In addition, some other areas such as Sampang, Pamekasan, and Sumenep are involved in drug abuse crime.

The fact that the number of drug crime increases proves that the existing law has not made the society wary and aware of the prohibition of drug abuse crime, as included in the Law number 35 of 2009 imposing criminal sanction in the form of special minimal punishment, 20 (twenty)-year imprisonment, life imprisonment, and death sentence. The punishment imprisonment is conducted based on drug class, type, size, and number. The solution taken to eradicate drug crime is to give the society the opportunity of reporting the case to the authorized one.

\section{h. Murder}

The problem of murder in Madura is always called carok (duel), while it is not due to carok. Carok, by Madura people, is defined as self-defense, usually due to some problems believed to be defended despite death as a bet, for example when one's wife is tempted or taken by others, land affairs, and revenge problems. However, when one party cannot accept the reality and files lawsuit to the court, the court calls it a crime resulting in life toll.

Murder is a crime resulting life toll, either straightforwardly or disguisedly, against which articles 338, 339, 340, 342, 344, and 345 KUHP (Penal Code) impose 12-, 15-, and 20-year imprisonment. However, although KUHP has governed this case in such a way, some people in Madura still do this crime. It can be seen from the case of murder against a family occurring in Sumenep Regency some months ago. To resolve this case and to prevent any further murder from occurring, Madura people still transcend resolution by means of discussion with society leaders and victim's family.

\section{i. Conflict due to Different Religions}

Dynamics related to Conflict of Different Religions is becoming a hot issue amid the society. Inter-religion sect conflicts are found almost easily every year in many Indonesian areas, including in rural inland area of Madura. This problem becomes serious when it is supported with attitudes emphasizing more on the certain extinct religion than on resolving it in peaceful condition and kinship principle.

So far, the inter-religion sects conflict occurring in Madura that has ever surfaced and colored 
a variety of national and international media was sunni-syiah stream difference in Sampang Regency on December 26, 2011. This incidence indicates that inter-religion stream conflict and violence are the conflict leading the peaceful life of Indonesian people to be inapplicable well (see: Kontras: 2011).

Considering the observation conducted, the legal problem related to this different sects starts to occur in some areas of Madura. In Pamekasan Regency, about 4 conflicts between religion sects occurred likely leading to violence between individual adherents of different religion. Those conflicts are:

1. Conflict between sunni sect and a spiritual sect called "Ajaran Falsafah dalam Satu Bahasa Agama (Philosophical Tenet in One Religion Language)". The actor of this sect dissemination was "Ki Bashirah Ibnullah". This incidence occurred in Dasok Village of Pademawu Sub District of Pamekasan on December 16, 2013. This conflict resolution is conducted through dialog between two parties facilitated by village apparatus and local sector police officer. ${ }^{2}$

2 Conflict between sunni sect and "seroja" sect adherents occurring in Pagagan Village of Pamekasan. This problem can be resolved later through approach and dialogue initiated by kyai and local religion leaders. This incidence occurs along $2012 .^{3}$

3 Conflict between adherents of Lembaga Dakwah Islam Indonesia (LDII = Indonesian Islam Proselytizing Institution) and sunni society objected with the existence of LDII sect adherents. This commotion has colored the process of resolving the conflict, but it can be resolved through dialogue between their religion leaders. This event occurs on November 19, 2011 in Batu Kerbu Village, Pasean, Pamekasan. ${ }^{4}$

4. Conflict between "Nganyareh Syahadat" and Sunnit sects occurring on Aprl 2008. This incidence has made the people in Larangan Tokol Village of Tlanakan Sub District of Pamekasan Regency tumultuous. ${ }^{5}$

The four conflicts in fact did not involve police officers and other law apparatuses, but were resolved through dialog only, initiated by village head, religion leaders, and other parties.

\section{Three-Pillar Synergism Reinforcement Model in Judicial Function}

Village is the smallest unit and all at once, the starting point of Indonesian development. It means that a state's goodness is determined by the village's good governance. Village plays a very vital part in the attempt of Indonesian development. From an in-depth study, it can be seen that discussing about village is not as simple as its apparently small scope.

There are many definitions of village, dependent on from which point of view an individual defines it. Nevertheless, those many definitions are formulated in the provision of Article 1 clause (1) of Law No.6 of 2014 about Village mentioning that: village is village or customary village called in other name, thereafter called Village, the legal society unit having territorial border authorized to govern and to deal with government affairs and local society interest

2 Interview with KH. Wakid Abdullah, religious leader in Dasok Village. Interview was conducted on July 30 , 2016 Mushalla Al-Amin desa Dasok.

3 Interview with Sukardi, Chief of Government Division of Pegagan Village. . Interview was conducted on July 27, 2016 in Pagagan Village Office.

4 Interview with Ansori Jamil, religious leader of Batu Kerbuy Village. Interview was conducted on July 30, 2016, in Masjid Baiturrahman, Pasean.

5 Interview with KH. Moh. Mahfudz Abd. Mukthi, Leader of Pesantren Al-Mukthi, Larangan Village, Tokol Pamekasan 
based on society's initiative, origin right, and/or traditional right recognized and respected in the Republic of Indonesia state's (NKRI) government system". In this definition, village can have another name, for example: customary village and other name united by legal society in governing their own affairs, in the term of government, society development, cultural preservation and society character, and other society interests in the frame of NKRI.

The attempt of giving the village the autonomy has been actually implied in some provisions of Article in Law No.24 of 2004 about Local Government, in which this Law has given the village the authority of organizing its government independently. This provision develops into more positive direction since the enactment of Law No.6 of 2014 about Village. This Law actually provides a broad space to the attempt of giving village autonomy.

As the part of business in giving contribution to the attempt of creating autonomous village, this writing should give input to the village autonomy concept by developing and reformulating the institutional function of Village Head, Babinkamtibmas, and Babinsa as the institution given authority in solving the legal problem the villagers encounter. Optimizing the institutional function is expected to facilitate the villagers to solve their legal problems.

Such format as if is supported recalling that motto of village is to attempt to manage all of its peculiarities in realizing an independent village. The idea of optimizing institutional function in solving legal problem in the village can be the typical village product in solving its society's legal problem.

So far, society's perception on the existence of three institutions related to its function development as the legal problem resolving institution in village is responded to religiously by society. This perception ends up into two arguments: firstly, supporting fully the existence of three institutions as legal problem resolving institutions in village and secondly, not supporting the existence of three institutions as legal problem solver in village.

Meanwhile, their reason of agreeing is that basically the existence of institution is not only intended to manage government system in village. The existence of institution actually serves to protect and to build society in daily life, including in legal problem. It is in line with Sabitullah confirming that there should be an institution authorized to deal with and to solve any legal problem in village.

Furthermore, Sabit explains that the society still factually expects and practices legal resolution through the society leaders as inheritance from tahkim embraced by villagers far before the colonial came to this country. ${ }^{6}$ Simply, tahkim concept facilitates the society in dealing with its legal problem (Daud Ali: 2006). Usually a individual who is encountering legal problem will come to a kyai or Islam scholars believed as having knowledge and smart solution related to the problem encountered. In this case, the existence of Islam scholars plays an important role in solving legal problem in the village.

Similarly, Nurhadi supports the development and the expansion of institutional function for the three institutions in solving problems at village level. Even Nurhadi views optimistically that this concept will facilitate the society to solve any legal problems encountered maximally.

6 Interview with Sabitullah, youth leader in Buluh Village, Socah Sub district, Bangkalan Regency. Interview was conducted on July 15, 2016 in Buluh Village office.

7 Interview with Nurhadi, society leader of Gilianyar Village, Kamal Sub District, Bangkalan Regency. Interview on July 15, 2016 in Kamal Sub District Office. 
Meanwhile, those declining the giving of institutional authority to Village Head, Babinkamtibmas and Babinsa in solving legal problem at village level because the existence of three institutions is unlikely to be given authority. As Badrul Kamal suggests, the optimization of the three institutions' performance is more important and beneficial than the increase of authority in solving the legal problem.

Nevertheless, Kamal does not reject the existence of a society leader to be authorized to solve the legal problem. Kamal adds that the reality occurring is that there are still many villagers prefer solving their legal problem through society and religious leaders. It is because the resolution process is not as complicated as the formal resolution.

When observed closely, the main function of Bhabinkamtibmas, based on Peraturan Kapolri No.3 of 2015 about Society Policing, includes:

1. Visiting the society to: listen to their complaint about the problem of Kamtibmas and to give explanation and solution to it, to maintain silaturahmi / fraternity relation;

2. Guiding and giving education in legal and Kamtibmas sector to improve legal awareness and Kamtibmas by upholding Human Rights;

3. Disseminating information about Polri's leader policy related to the Maintenance of Society Security and Orderliness (Harkamtibmas);

4. Supporting the implementation of sikamling (mobile security system) in securing environment and society activity;

5. Giving police service to those needing;

6. Activating the positive society activities;

7. Coordinating the attempt of building Kamtibmas with village/kelurahan sets and other related parties;

8. Consulting, mediating, negotiating, facilitating, motivating the society in Harkamtibmas and solving criminal and social problems.

Considering those main functions, the duty of Bhabinkamtibmas includes:

1. Conducting door-to-door visiting to all of its assignment areas;

2. Conducting and helping problem solving;

3. Governing and securing the society activity;

4. Receiving information about crime;

5. Giving temporary protection to the mislead person and the victims of crime and infringement;

6. Participating in helping the victim of natural disaster and disease epidemic;

7. Guiding and directing the society or community related to Kambtibmas problem and Polri's Service.

Considering this, the authorities given, based on the provision of Article 28 of Peraturan Kapolri Number 3 of 2015 are:

1. Resolving the quarrel between members of society or community;

2. Taking some necessary measures as the follow-up of FKPM consensus in maintaining the environment security; 
3. Visiting the venue (TKP) and taking the first action in the venue (TPKP).

4. Overseeing the traditional belief existing in the society that can generates disunity or threats the nation's unity and integrity.

Thus, institutionally, Bhabinkamtibmas has an authority of solving legal problem occurring within society. It is as if supported through Article 26 clause (4) of Law No.6 of 2014 mandating the Village Head to reconcile his/her quarreling people. As the one in charge of building society security and orderliness, the Village head is required to give the best solution to any legal problem befalling his/her people. Meanwhile, the role of Babinsa in society is to create orderliness and security at village level (Kompas: 2013).

The three authorities given to three institutions have been actually fulfilled criteria in order to realize the function of institutions as the one given authority to solve the legal problem of village society. Meanwhile, the declination against this three-institution synergism establishment in solving legal problem is likely because they understand poorly the duty, function, and authority of the three institutions.

The three-pillar institutionalization is the rule model that can be an instrument of developing the law in Indonesia, particularly for the poor people generally living in rural areas. Until today, villagers still found limited access formalistically to judicature institution in the context of searching for legal justice, from legal system, regulation, and government's inadequate attention so that the contribution of state to the institutionalization of legal existing in rural poor people has not been felt well in this Three-Pillar context.

This Three-Pillar Policy model is in line with Legal Development Theory initiated by Mochtar Kusumaatmadja, in which he refers to the society's ideology including legal structure, culture, and substance. This theory is actually an adaptation to a theory developed by Roscoe Pond about "law as a tool of social engineering", in which at that time, this theory develops in American society and state's life. ${ }^{8}$ In his view, Mochtar Kusumatmadja gives us an understanding that law is not only defined as a tool but law is defined as a means of building society. This thinking construction is based on a belief that orderliness and regularity in development and reformation attempt is indeed absolutely needed. In other words, there should be a law in the sense of norm expected to direct human activity to the direction intended by the development and reformation. For that reasons, there should be a non-written rule and ordinance that should be consistent with the law living in the society. It means that values developing and recognized in society life is the part of society's legal norm that should be utilized and expedient to the society life.

\section{CONCLUSION}

Several legal problems the rural people often encounter are: trading, inheritance, debt-loan, land affairs, cockfighting gambling, drug, murder, and conflict of different religious sects. Basically, the society has had its own way of solving any legal problem, through society leaders, village apparatus, kyai, and other method out of formal way specified by the state. Although there are different perceptions on an idea of institutionalizing the authorities of Village Head, Bhabinkamtibmas, and Babinsa in solving legal problem at village level, but when observed closely, those three institutions have the authority over it.

The institutionalization of Three Pillars in the form of policy model in Village Regulation form

8 See Lili Rasjidi and Ida Bagus Wiyasa Putra, Hukum sebagai Suatu Sistem, Publisher: CV. Mandar Maju, Bandung, 2003, p. 5 . 
actually intended to construct and to enforce the law in the context of village and village government in Madura is one of certainties that cannot be underestimated as it is a legal breakthrough in approaching the process of prevention and law enforcement.

\section{RECOMMENDATION}

One of effective instruments to grow and develop the prestigious villager life from legal aspects is to institutionalize the Three Pillars in judicial function through village regulation to make the society's law awareness runs effectively and well, recalling that these Three Pillar's leadership is actually felt and acceptable to rural society, particularly in Madura, culturally, socially, religiously, and economically.

\section{ACKNOWLEDGMENT}

Thank to the Research, Technology and High Education Ministry for funding this research.

\section{REFERENCES}

A. Latif Wiyata. 2006. Carok, Konflik Kekerasan dan Harga Diri Orang Madura. Yokyakarta; LKiS

A. Tumpa, Harifin, 2010, disampaikan dalam pidato pembukaan "Konferensi Regional Asosiasi Internasional Administrator Pengadilan (IACA)" di Istana Bogor, Jawa Barat

Ayu Sutarti. 2014. Orang Madura di Mata Orang Jawa. Prosiding Seminar Nasional Budaya Madura I; Madura Dalam Kacamata Sosial, Budaya, Ekonomi, Agama, Kebahasaan, dan Pertanian. Puslit Budaya dan Potensi Madura LPPM Universitas Trunojoyo Madur

Bambang Sunggono, 2010, Metodologi Penelitian Hukum, Raja Grafindo Persada, Jakarta

Faisal, Sanapiah.,1990 Penelitian Kualitatif (Dasar-dasar Aplikatif), Yayasan Asih Asah Asuh, Malang.

Ikhwan, Mufarrijul dkk, 2008, "Pengelolaan Perikanan Berbasis Masyarakat (PPBM) Sebagai Upaya Resolusi Konflik Di Perairan Selat Madura(Studi Kasus Kabupaten Bangkalan)", Laporan hasil Penelitian PHB,DP2M/DIKTI

Lili Rasjidi dan Ida Bagus Wiyasa Putra, 2003, Hukum sebagai Suatu Sistem, Penerbit: CV. Mandar Maju, Bandung.

Mahadi, 1997, "Inventarisasi Ringkasan Tulisan-tulisan dan Jurisprudensi dari Zaman Sebelum 1945", Hasil Kerjasama BPHN dan Fakultas Hukum USU, Medan.

Mustopadidjaja, "Studi Kebijaksanaan, Perkembangan, dan Penerapannya dalam Rangka Administrasi dan Managemen Pembangunan”, LP- FE-UI, Jakarta, 1992.

Purba, Rehngena, 2001. "Pilihan Penyelesaian Sengketa di Luar Pengadilan (Studi Kasus Fungsi Lembaga Runggun Adat pada Masyarakat Karo di Kabupaten Karo) ”, Jurnal Fakultas Hukum UNAIR -Yuridika, Vol. 12, No. 3.

Sudikno Mertokusumo, 1983 "Sejarah Peradilan dan Perundang-Undangannya di Indonesia Sejak 1942 dan Apakah Kemanfaatannya Bagi Kita Bangsa Indonesia”, Yogyakarta.

Taufiqurrahman. 2006. Islam dan Budaya Madura. Makalah dipresentasikan pada forum Annual Conference on Contemporary Islamic Studies, Direktorat Pendidikan Tinggi Islam, Ditjen Pendidikan Islam, Departemen Agama RI, di Grand Hotel Lembang Bandung. 
Mukhlis, Safi, Rina Yulianti : A Three-pillar Synergism Reinforcement Model In Judicial .....

Widjaja, HAW, 2003. "Otonomi Desa Merupakan Otonomi Yang Asli, Bulat dan Utuh", RajaGrafindo Persada, Jakarta.

Witanto, Darmoko Yuti, 2008, "Hukum Adat Laut Sabang, Kearifan-Kearifan yang Terlupakan”, Kompas, Jakarta.

Yulianti, Rina dkk, 2009, 'Laporan Hasil Penelitian (Rekonseptualisasi Fungsi Lembaga Adat Sebagai Pilihan Peneyelesaian Sengketa di Luar Pengadilan di Wilayah Pulau Terpencil (Studi kasus Kabupaten Sumenep), DP2M-DIKTI. Telah diseminarkan di SEBUMI International Conference, UKM, Malaysia, 12-13 Oktober 2010.

Yuriadi. 2014. Carok dan Harga Diri Masyarakat Madura Dalam Prespektif Psikologi. Prosiding Seminar Nasional Budaya Madura I; Madura Dalam Kacamata Sosial, Budaya, Ekonomi, Agama, Kebahasaan, dan Pertanian. Puslit Budaya dan Potensi Madura LPPM Universitas Trunojoyo Madura

Village Justice In Indonesia, 2009, “Studi kasus tentang akses terhadap keadilan, demokrasi dan pemerintahan desa”, Laporan keluaran Social Development Unit, Bank Dunia di Indonesia bekerjasama dengan tim Justice for the Poor . 